\title{
Antioxidant activity, determination of total phenolic and flavonoid content of Muntingia calabura L. Extracts
}

\section{Aktivitas antioksidan, penetapan kadar fenolik total dan flavonoid total ekstrak daun kersen (Muntingia calabura L.)}

\author{
Anita Dwi Puspitasari", Ririn Lispita Wulandari \\ Fakultas Farmasi Universitas Wahid Hasyim Semarang \\ Jl. Menoreh Tengah X/22 Sampangan Semarang 50236
}

\begin{abstract}
ABSTRAK
Daun Kersen (Muntingia calabura L.) mengandung alkaloid, saponin, fenolik, flavonoid, dan tanin. Senyawa fenolik dan flavonoid memiliki aktivitas antioksidan. Penelitian ini bertujuan untuk menentukan aktivitas antioksidan, penetapan kadar fenolik total dan flavonoid total ekstrak etanol daun kersen. Daun kersen dimaserasi menggunakan etanol 96\% lalu diuapkan hingga diperoleh ekstrak etanol. Ekstrak etanol dilarutkan ke dalam air lalu dipartisi dengan $n$ heksan dan etil asetat untuk memperoleh fraksi $n$ heksan, fraksi etil asetat, dan fraksi air. Pengujian aktivitas antioksidan dari ekstrak dan fraksi-fraksi dilakukan dengan metode pengukuran penangkapan radikal bebas oleh 1,1difenil-2-pikrilhidrazil (DPPH) secara in vitro. Vitamin C digunakan sebagai kontrol positif dengan nilai $\mathrm{IC}_{50} 25,74 \mu \mathrm{g} / \mathrm{mL}$. Kandungan fenolik total dan flavonoid total ditentukan dengan menggunakan metode kolorimetri menggunakan standar asam galat untuk fenolik total dan standar kuersetin untuk flavonoid total. Hasil penelitian menunjukkan bahwa fraksi etil asetat menunjukkan aktivitas antioksidan paling tinggi dengan nilai $\mathrm{IC}_{50} 79,37 \mu \mathrm{g} / \mathrm{mL}$ dibanding fraksi $\mathrm{n}$ heksan $(101,36 \mu \mathrm{g} / \mathrm{mL})$, ekstrak etanol $(126,47 \mu \mathrm{g} / \mathrm{mL})$, dan fraksi air $(129,85 \mu \mathrm{g} / \mathrm{mL})$. Fraksi etil asetat mengandung kadar fenolik total paling tinggi yaitu sebesar 510,57 mg GAE/g ekstrak dibanding ekstrak etanol $(311,10$ mg GAE/g ekstrak), fraksi air (292,74 mg GAE/g ekstrak), dan fraksi n heksan (103,95 mg GAE/g ekstrak). Fraksi etil asetat mengandung kadar flavonoid total paling tinggi yaitu sebesar 76,32 mg QE/g ekstrak dibanding ekstrak etanol (39,63 mg QE/g ekstrak), fraksi air (14,29 mg QE/g ekstrak), dan fraksi $\mathrm{n}$ heksan 3,30 mg QE/g ekstrak). Kadar fenolik total dan flavonoid total berkorelasi positif terhadap aktivitas antioksidan.
\end{abstract}

Kata kunci: antioksidan, fenolik, flavonoid, Muntingia calabura 


\begin{abstract}
Muntingia calabura L. leaves were contained alkaloids, saponins, phenolic, flavonoids, and tannin. Phenolic and flavonoids compound had antioxidant activity. The present study aims to determine the antioxidant activity, determination of total phenolic and flavonoid content of ethanol extract of Muntingia calabura L. leaves and its fractions. Muntingia calabura L. leaves were macerated with $96 \%$ ethanol and then evaporated until ethanol extract was obtained. The ethanol extract was dissolved into water and then partitioned with $n$ hexane and ethyl acetate to obtain the $n$ hexane fraction, ethyl acetate fraction and water fraction. Determination of antioxidant activity of extracts and fractions was performed by free radical capture measurement method by 1,1-diphenyl-2picrylhydrazyl (DPPH) in vitro. Vitamin $\mathrm{C}$ was used as a positive control with $\mathrm{IC}_{50}$ value of $25.74 \mu \mathrm{g} / \mathrm{mL}$. The total phenolic and flavonoid content were determined using the colorimetric method using standard gallic acid for total phenolics and standard quercetin for flavonoid content. The results showed that ethyl acetat fraction showed the highest antioxidant activity with $\mathrm{IC}_{50} 79.37$ $\mu \mathrm{g} / \mathrm{mL}$ value compared to $\mathrm{n}$ hexane fraction $(101.36 \mu \mathrm{g} / \mathrm{mL})$, ethanol extract $(126.47 \mu \mathrm{g} / \mathrm{mL})$, and water fraction $(129.85 \mu \mathrm{g} / \mathrm{mL})$. The ethyl acetate fraction contains the highest total phenolic of 510.57 $\mathrm{mg} \mathrm{GAE} / \mathrm{g}$ extract compared to ethanol extract (311.10 mg GAE/g extract), water fraction $(292.74 \mathrm{mg}$ GAE/g) extract, and $\mathrm{n}$ hexane fraction (103.95 mg GAE/g extract). The ethyl acetate fraction contained the highest flavonoid content of $76.32 \mathrm{mg}$ QE/g extract compared to ethanol extract (39.63 $\mathrm{mg}$ QE/g extract), water fraction (14.29 mg QE/g extract) and $\mathrm{n}$ hexane fraction $(3.30 \mathrm{mg}$ QE/g extract). Total phenolic and total flavonoid levels were positively correlated with antioxidant activity.
\end{abstract}

Keywords: antioxidant, phenolic, flavonoid, Muntingia calabura

\title{
PENDAHULUAN
}

Dewasa ini, dunia kedokteran banyak membahas mengenai radikal bebas (free radical). Radikal bebas terlibat dalam penyakit degenerative seperti pathogenesis diabetes, kerusakan hati, inflamasi, kanker, gangguan jantung, gangguan syaraf dan proses penuaan (Onkar et al., 2012). Oleh sebab itu, dibutuhkan antioksidan yang dapat membantu melindungi tubuh dari serangan radikal bebas dan meredam dampak negatifnya (Winarsi, 2011). Antioksidan bekerja dengan cara melengkapi kekurangan elektron yang dimiliki radikal bebas dan menghambat terjadinya reaksi berantai dari pembentukan radikal bebas yang dapat menimbulkan stres oksidatif (Yuliarti, 2008). Antioksidan dapat diproduksi secara sintetik dan alami tetapi antioksidan sintetik memiliki efek toksik dibandingkan antioksidan alami (Shirmila et al., 2013). Beberapa efek yang ditimbulkan oleh antioksidan sintetik adalah seperti alergi, asma, radang hidung, sakit kepala, kemerahan, urtikaria, masalah pada mata dan perut, serta penurunan kesadaran (Race, 2009). Oleh karena itu perlu dilakukan berbagai penelitian dalam pencarian antioksidan alami untuk menggantikan antioksidan buatan.

Salah satu tanaman yang berkhasiat sebagai antioksidan alami adalah daun kersen (Muntingia calabura L). Kersen, banyak dijumpai di pinggir jalan, tumbuh di tengah retakan rumah, di tepi saluran pembuangan air dan tempat-tempat yang kurang kondusif untuk hidup karena kersen mempunyai kemampuan beradaptasi yang baik. Secara empiris daun kersen digunakan untuk pengobatan batuk, penyakit kuning, dan asam urat. Menurut Danugroho dan Widyaningrum (2014), ekstrak infusa daun kersen memiliki aktivitas sebagai analgesik yang telah diuji pada mencit jantan ras swiss. Daun kersen mengandung senyawa flavonoid, saponin, polifenol dan tanin (Kuntorini et al., 2013). Terdapat penelitian bahwa tumbuhan yang mengandung senyawa metabolit sekunder berupa flavonoid dan fenol berguna sebagai penangkap radikal bebas, yang memiliki aktivitas sebagai antioksidan (Nishantini et al., 2012). Flavonoid merupakan senyawa metabolit sekunder dan termasuk komponen fenolik yang bertindak sebagai pertahanan yang baik terhadap radikal hidroksil dan 
superoksida dengan melindungi membran lipida terhadap reaksi oksidasi yang merusak (Lee et al., 2003). Penelitian mengenai aktivitas antioksidan daun kersen (Muntingia calabura L.) dengan metode DPPH menggunakan pembanding antioksidan sintetik BHT telah dilakukan oleh Latifah (2015). Hasil penelitian tersebut menunjukkan bahwa ekstrak etanol mempunyai potensi aktivitas antioksidan paling besar dengan $\mathrm{IC}_{50} 34,732 \mathrm{mg} / \mathrm{L}$ dibanding ekstrak n heksan dan etil asetat. Ekstrak metanol daun kersen mengandung total fenol sebesar $0,903 \mu \mathrm{g} / \mathrm{mL}$ dengan pembanding asam galat dan $2,9 \mu \mathrm{g} / \mathrm{mL}$ dengan pembanding asam tanat (Siddiqua, 2010). Kadar flavonoid total dalam ekstrak etanol daun kersen dengan metode maserasi sebesar $0,216 \% \mathrm{~b} / \mathrm{b}$ dan metode sokletasi sebesar $0,216 \% \mathrm{~b} / \mathrm{b}$ dengan pembanding kuersetin (Puspitasari and Prayogo, 2016). Penelitian tentang korelasi antara kandungan fenolik total dan flavonoid total terhadap aktivitas antioksidan belum banyak dilaporkan.

Dari uraian diatas, maka tujuan dari penelitian ini adalah untuk menentukan aktivitas antioksidan, penetapan kadar fenolik total dan flavonoid total ekstrak etanol daun kersen. Menentukan korelasi antara kandungan fenolik total dan flavonoid total terhadap aktivitas antioksidan. Ekstrak etanol daun kersen difraksinasi bertingkat berdasarkan kepolaran pelarut yaitu mulai dari $n$ heksan, etil asetat, dan air. Fraksinasi bertingkat ini dilakukan untuk memisahkan senyawa-senyawa berdasarkan tingkat kepolarannya.

\section{METODE PENELITIAN \\ Alat dan Bahan}

Alat-alat yang digunakan yaitu neraca analitik And GR-300, rotary evaporator Ryela N-1000, spektrofotometer UV-Vis Shimadzu UV Mini 1240, ultrasonic cleaner WT-600-40, dan waterbath Eyela SB-1000. Bahan uji yang digunakan adalah daun kersen (Muntingia calabura L.). Bahan kimia yang digunakan meliputi DPPH (MERCK), $\mathrm{AlCl}_{3} 10 \%, \mathrm{NaOH} 1 \mathrm{M}$, Asam Galat, pereaksi Folin Ciocalteu (MERCK), Vitamin C (Phytotechnology Laboratoreis), Kuersetin (Sigma Aldrich), pereaksi dragendorff, pereaksi Mayer, $\mathrm{H}_{2} \mathrm{SO}_{4}$ pekat, aquades, $\mathrm{n}$ heksan, etil asetat, dan etanol $96 \%$

\section{Jalannya Penelitian \\ Penyiapan bahan}

Daun kersen (Muntingia calabura L.) dengan spesifikasi tidak terlalu muda diperoleh dari kelurahan Sampangan Kecamatan Gajahmungkur Semarang. Daun kersen dilakukan determinasi untuk mengetahui identitas bahan tanaman yang digunakan untuk penelitian.

Daun disortir, dicuci kemudian dikeringkan dengan menggunakan oven selama 3 hari. Daun yang telah kering diserbuk dengan blender kemudian diayak menggunakan ayakan 60 mesh sehingga diperoleh bubuk daun kersen.

\section{Pembuatan ekstrak etanol}

Proses ekstraksi dilakukan dengan metode maserasi menggunakan pelarut etanol 96\%. Empat ratus gram serbuk daun kersen dimasukkan ke dalam toples lalu ditambahkan $3 \mathrm{~L}$ pelarut etanol $96 \%$. Toples dilapisi kertas coklat agar terhindar dari cahaya matahari langsung dan ditutup aluminium foil. Proses perendaman selama 3 hari dan dilakukan pengadukan selama 15 menit tiap 8 jam sekali. Setelah 3 hari, dilakukan penyaringan sehingga didapat maserat 1. Ampas dari penyaringan ditambahkan $1 \mathrm{~L}$ pelarut etanol 96\% dan dilakukan perendaman ulang (remaserasi) selama 1 hari dan dilakukan penyaringan kembali sehingga didapat maserat 2. Maserat 1 dan maserat 2 dienapkan semalam kemudian dipekatkan menggunakan rotary evaporator pada suhu $45^{\circ} \mathrm{C}$ sehingga diperoleh ekstrak etanol.

\section{Pembuatan fraksi n heksan, fraksi etil asetat, dan fraksi air}

Ekstrak etanol 5 gram dilarutkan dalam $10 \mathrm{~mL}$ etanol 96\% ditambah $100 \mathrm{~mL}$ n heksan dan 90 $\mathrm{mL}$ aquadest yang kemudian dimasukkan corong pisah, digojog hingga memisah (lapisan atas adalah fraksi $\mathrm{n}$ heksan lapisan bawah adalah fraksi air) kemudian dipisahkan. Pengulangan dilakukan 
sebanyak 4 kali. Fraksi air ditambah $100 \mathrm{~mL}$ etil asetat kemudian dimasukkan corong pisah, digojog hingga memisah (lapisan atas fraksi etil asetat dan lapisan bawah fraksi air) kemudian dipisahkan. Pengulangan dilakukan sebanyak 4 kali.

\section{Identifikasi fitokimia ekstrak dan fraksi daun kersen (Harborne, 1987) Identifikasi saponin}

Ekstrak etanol, fraksi $\mathrm{n}$ heksan, fraksi etil asetat, dan fraksi air masing-masing ditimbang 100 mg kemudian ditambahkan $10 \mathrm{~mL}$ aquades panas dalam tabung reaksi. Selanjutnya digojog kuat selama 10 detik maka akan terbentuk buih yang mantap setinggi $1-10 \mathrm{~cm}$ dalam waktu 10 menit. Kemudian ditambahkan 1 tetes $\mathrm{HCl} 2 \mathrm{~N}$ dan diamati. Reaksi positif akan terbentuk busa yang stabil.

\section{Identifikasi tanin}

Ekstrak etanol, fraksi n heksan, fraksi etil asetat, dan fraksi air masing-masing ditimbang 100 mg kemudian ditambah $10 \mathrm{~mL}$ air panas dan 5 tetes $\mathrm{FeCl}_{3} 1 \%$. Perubahan warna diamati. Reaksi positif akan terbentuk warna hijau kehitaman.

\section{Identifikasi fenolik}

Ekstrak etanol, fraksi $n$ heksan, fraksi etil asetat, dan fraksi air masing-masing ditimbang 100 mg kemudian dimasukkan cawan porselen dan dilarutkan dengan pelarut masing-masing kemudian ditambahkan aquades $5 \mathrm{~mL}$ lalu disaring dengan kertas saring dan dimasukkan ke dalam tabung reaksi dan ditambahkan 5 tetes $\mathrm{FeCl}_{3}$. Perubahan warna yang terjadi diamati. Reaksi positif menghasilkan warna jingga.

\section{Identifikasi flavonoid}

Ekstrak etanol, fraksi $\mathrm{n}$ heksan, fraksi etil asetat, dan fraksi air masing-masing ditimbang 100 mg kemudian dilarutkan dengan pelarut masing-masing kemudian ditambahkan aquades panas $5 \mathrm{~mL}$ dan disaring menggunakan kertas saring. Masing-masing larutan dimasukkan ke dalam tabung reaksi kemudian ditambahkan 10 butir $\mathrm{MgCl}_{2}$ dan $\mathrm{HCl}$ pekat (37\%) sebanyak 5 tetes, digojog dan diamati perubahan warna yang terjadi. Reaksi positif akan menghasilkan warna jingga.

\section{Identifikasi alkaloid}

Ekstrak etanol, fraksi $n$ heksan, fraksi etil asetat, dan fraksi air masing-masing ditimbang 100 mg kemudian dilarutkan pada pelarut masing-masing dan ditambahkan $5 \mathrm{~mL} \mathrm{HCl} 2 \mathrm{~N}$ kemudian dibagi ke dalam 3 tabung reaksi. Masing-masing tabung dilakukan penambahan pereaksi. Tabung pertama ditambahkan 3 tetes $\mathrm{HCl} 2 \mathrm{~N}$ sebagai blangko. Tabung kedua ditambahkan 3 tetes pereaksi dragendroff dan tabung ketiga ditambahkan pereaksi mayer sebanyak 3 tetes. Perubahan warna yang terjadi diamati. Reaksi positif akan menghasilkan warna jingga.

Uji aktivitas antioksidan (Blois, 1958)

\section{Penyiapan larutan DPPH}

DPPH ditimbang seberat 9,8 mg dilarutkan dalam etanol p.a hingga $250 \mathrm{~mL}$ sehingga diperoleh larutan dengan konsentrasi $0,1 \mathrm{mM}$.

\section{Penyiapan larutan vitamin $\mathrm{C}$}

Vitamin C ditimbang sebanyak $10 \mathrm{mg}$ kemudian dilarutkan dengan etanol p.a dalam labu takar 100 $\mathrm{mL}$ hingga tanda batas sehingga diperoleh larutan dengan konsentrasi $100 \mathrm{ppm}$.

\section{Penyiapan larutan sampel}

Masing-masing ekstrak etanol, fraksi n heksan, fraksi etil asetat, dan fraksi air ditimbang $50 \mathrm{mg}$ dilarutkan dengan etanol p.a $10 \mathrm{~mL}$ dalam gelas beker $50 \mathrm{~mL}$ dan dihomogenkan dengan menggunakan magnetic stirrer kemudian dimasukkan dalam labu takar $50 \mathrm{~mL}$ dan ditambahkan etanol p.a sampai tanda batas sehingga diperoleh larutan dengan konsentrasi 1000 ppm. 


\section{Penentuan panjang gelombang maksimum}

Larutan DPPH 0,1 mM dimasukkan dalam kuvet kemudian dibaca absorbansinya dengan blangko etanol p.a pada range $450-550 \mathrm{~nm}$.

Penentuan Operating Time (OT)

Vitamin C dengan konsentrasi 6 ppm dipipet $1 \mathrm{~mL}$ ditambah DPPH sebanyak $4 \mathrm{~mL}$ kemudian dibaca pada panjang gelombang maksimum hingga absorbansi stabil.

\section{Penentuan aktivitas antioksidan}

Sampel ekstrak etanol, fraksi n heksan, fraksi etil asetat, dan fraksi air dibuat larutan dengan konsentrasi 5, 10, 15, 20, dan 25 ppm. Masing-masing konsentrasi larutan tersebut dipipet sebanyak 1 mL dan ditambahkan $4 \mathrm{~mL}$ larutan DPPH 0,1 mM. Campuran dihomogenkan dan didiamkan ditempat gelap selama operating time. Serapan larutan sampel diukur dengan spektrofotometer UV-Vis pada panjang gelombang maksimum. Sebagai pembanding digunakan vitamin $C$ dengan konsentrasi 1, 2, 3, 4, 5, 6, 7, dan $8 \mathrm{ppm}$. Untuk larutan blangko, dari masing-masing seri larutan sampel dan standar diambil $1 \mathrm{~mL}$ kemudian ditambahkan $4 \mathrm{~mL}$ etanol p.a.

Penetapan kadar fenolik total (Pourmorad, 2006)

Penyiapan larutan asam galat

Asam galat ditimbang $10 \mathrm{mg}$ dilarutkan dalam etanol p.a hingga $10 \mathrm{~mL}$ sehingga diperoleh larutan dengan konsentrasi 1000 ppm.

\section{Penyiapan larutan sampel}

Masing-masing ekstrak etanol, fraksi $n$ heksan, fraksi etil asetat, dan fraksi air ditimbang 500 mg kemudian dimasukkan ke dalam gelas beker $50 \mathrm{~mL}$ dan dilarutkan dengan etanol p.a hingga larut dengan bantuan magnetic stirrer. Larutan disaring ke dalam labu takar $10 \mathrm{~mL}$ kemudian ditambahkan etanol p.a hingga tanda batas sehingga diperoleh konsentrasi masing-masing sebesar 50000 ppm.

\section{Penentuan panjang gelombang maksimum}

Pengukuran panjang gelombang maksimum menggunakan asam galat $150 \mathrm{ppm}$. Sebanyak 200 $\mu \mathrm{L}$ asam galat dengan konsentrasi $150 \mathrm{ppm}$ ditambahkan $400 \mu \mathrm{L}$ Folin Ciocalteu dan didiamkan selama 8 menit kemudian ditambahkan $4 \mathrm{~mL} \mathrm{Na} \mathrm{CO}_{3} 7 \%$. Dibaca pada spektrofotometer UV-Vis pada range $550-800 \mathrm{~nm}$.

\section{Penentuan operating time (OT)}

Pengukuran operating time menggunakan asam galat $6 \mathrm{ppm}$. Sebanyak $200 \mu \mathrm{L}$ asam galat dengan konsentrasi $150 \mathrm{ppm}$ ditambahkan $400 \mu \mathrm{L}$ Folin Ciocalteu dan didiamkan selama 8 menit kemudian ditambahkan $4 \mathrm{~mL} \mathrm{Na} \mathrm{CO}_{3} 7 \%$. Dibaca pada spektrofotometer UV-Vis pada panjang gelombang maksimum.

\section{Penentuan kadar fenolik total}

Sampel ekstrak etanol diencerkan 2 kali kemudian dipipet $200 \mu \mathrm{L}$, ditambahkan $400 \mu \mathrm{L}$ Folin Ciocalteu didiamkan selama 8 menit, ditambahkan $4 \mathrm{~mL} \mathrm{Na}_{2} \mathrm{CO}_{3} 7 \%$ ditunggu sampe 120 menit. Dibaca dengan spektrofotometer UV-Vis pada $\lambda$ maks $757,8 \mathrm{~nm}$ pada menit ke 30 setelah pencampuran. Replikasi dilakukan 3 kali. Perlakuan yang sama dilakukan juga pada sampel fraksi $n$ heksan, fraksi etil asetat, dan fraksi air. Sampel fraksi $n$ heksan dilakukan tanpa pengenceran, fraksi etil asetat dilakukan pengenceran sebanyak 2 kali dan fraksi air sebanyak 4 kali. Sebagai pembanding digunakan larutan asam galat dengan konsentrasi 50, 100, 150, 200, 250, dan 300 ppm.

Penetapan kadar flavonoid total (Chang, 2002) Penyiapan larutan kuersetin

Kuersetin ditimbang $20 \mathrm{mg}$ dan dilarutkan dengan $5 \mathrm{~mL}$ etanol p.a hingga larut. Larutan tersebut dimasukkan ke dalam labu takar $50 \mathrm{~mL}$ dan ditambahkan etanol p.a hingga tanda batas sehingga diperoleh konsentrasi larutan kuersetin sebesar 400 ppm. 


\section{Penyiapan larutan sampel}

Masing-masing ekstrak etanol, fraksi n heksan, fraksi etil asetat, dan fraksi air ditimbang 500 mg dimasukkan ke dalam gelas beker $50 \mathrm{~mL}$ kemudian dilarutkan dengan etanol p.a hingga larut dengan bantuan magnetic stirrer hingga larut. Kemudian larutan disaring ke dalam labu takar $10 \mathrm{~mL}$ ditambahkan etanol p.a hingga tanda batas sehingga diperoleh konsentrasi masing-masing sebesar 50000 ppm.

\section{Penentuan panjang gelombang maksimum}

Pengukuran panjang gelombang maksimum menggunakan kuersetin 2 ppm (Manik et al., 2014). Sebanyak $1000 \mu \mathrm{L}$ dari seri kuersetin konsentrasi 2 ppm ditambahkan $200 \mu \mathrm{L} \mathrm{AlCl}_{3} 10 \%$ dan $200 \mu \mathrm{L}$ $\mathrm{CH}_{3} \mathrm{COOK} 1 \mathrm{M}$. Kemudian dibaca dengan spektrofotometer UV-Vis pada range $400 \mathrm{~nm}-500 \mathrm{~nm}$.

\section{Penentuan operating time $(\mathrm{OT})$}

Pengukuran operating time menggunakan kuersetin 6 ppm. Sebanyak $1000 \mu \mathrm{L}$ dari konsentrasi kuersetin 6 ppm ditambahkan $200 \mu \mathrm{L} \mathrm{AlCl}_{3} 10 \%$ dan $200 \mu \mathrm{L} \mathrm{CH}_{3} \mathrm{COOK} 1 \mathrm{M}$. Kemudian dibaca pada spektrofotometer UV-Vis pada panjang gelombang maksimum.

\section{Penentuan kadar flavonoid total}

Sampel ekstrak etanol diencerkan 250 kali kemudian dipipet $1 \mathrm{~mL}$, ditambahkan $200 \mu \mathrm{L} \mathrm{AlCl} \mathrm{Al}_{3}$ $10 \%$ dan $200 \mu \mathrm{L}$ kalium asetat. Dibaca dengan spektrofotometer UV-Vis pada $\lambda$ maks $428,8 \mathrm{~nm}$ pada menit ke 30 setelah pencampuran. Replikasi dilakukan 3 kali. Perlakuan yang sama dilakukan juga pada sampel fraksi $n$ heksan, fraksi etil asetat, dan fraksi air. Sampel fraksi $n$ heksan dilakukan pengenceran sebanyak 25 kali, fraksi etil asetat sebanyak 400 kali dan fraksi air sebanyak 125 kali. Sebagai pembanding digunakan larutan kuersetin dengan konsentrasi 2, 4, 6, 8, 10, dan 12 ppm.

\section{Analisis Data}

Aktivitas antioksidan sampel ditentukan dengan besarnya hambatan serapan DPPH (\% inhibisi) da $\mathrm{IC}_{50}$ pada masing-masing sampel. $\mathrm{IC}_{50}$ yaitu konsentrasi sampel yang menyebabkan penangkapan radikal bebas sebesar $50 \%$.

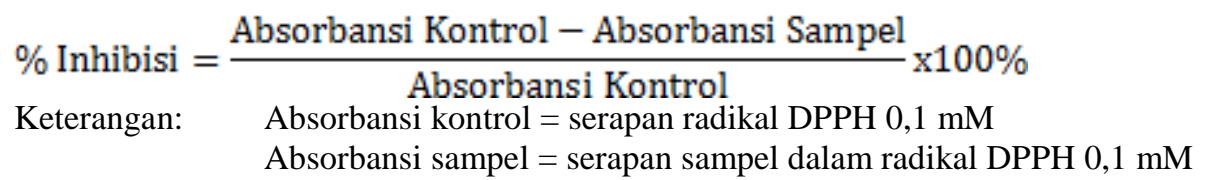

Kadar fenolik total diperoleh dari nilai absorbansi masing-masing sampel kemudian diplotkan kedalam persamaan kurva baku asam galat. Nilai yang didapat dikalikan volume total sampel dan dibandingkan dengan bobot penimbangan dengan rumus:

Kadar fenolik total $=\frac{\mathrm{X} \times \mathrm{Fpx} \text { Volume total ekstrak }}{\text { bobot penimbangan (gram) } \mathrm{x} 1000}(\mathrm{mg} / \mathrm{gram})$

Ket: $\mathrm{Fp}=$ Faktor pengenceran

Kadar flavonoid total diperoleh dari nilai absorbansi masing-masing sampel kemudian diplotkan kedalam persamaan kurva baku kuersetin. Nilai yang didapat dikalikan volume total sampel dan dibandingkan dengan bobot penimbangan dengan rumus:

$$
\text { Kadar flavonoid total }=\frac{\text { X x Fp x Volume total ekstrak }}{\text { bobot penimbangan }(\mathrm{gram}) \mathrm{x} 1000}(\mathrm{mg} / \mathrm{gram})
$$

Ket: $\mathrm{Fp}=$ Faktor pengenceran 


\section{HASIL DAN PEMBAHASAN}

Hasil determinasi dari daun kersen yang digunakan dalam penelitian ini adalah spesies Muntingia calabura L. Ekstrak daun kersen (Muntingia calabura L.) dibuat dengan metode maserasi menggunakan pelarut etanol 96\%. Ekstrak etanol difraksinasi bertingkat menggunakan pelarut $\mathrm{n}$ heksan dan etil asetat sehingga diperoleh fraksi $n$ heksan, fraksi etil asetat, dan fraksi air. Rendemen ekstrak etanol daun kersen dan fraksi-fraksinya dapat dilihat pada Tabel I.

\section{Tabel I. Rendemen ekstrak dan fraksi}

\begin{tabular}{ccc}
\hline Sampel & Berat sampel (gram) & $\begin{array}{c}\text { Rendemen } \\
(\boldsymbol{\%})\end{array}$ \\
\hline Ekstrak Etanol & 70 & 17,5 \\
Fraksi etil asetat $^{*}$ & 5 & 20 \\
Fraksi n heksan $^{*}$ & 10 & 40 \\
Fraksi air $^{*}$ & 5 & 20 \\
\hline
\end{tabular}

Keterangan:

*dihitung terhadap berat ekstrak etanol yang difraksinasi

Ekstrak etanol, fraksi etil asetat, fraksi n heksan, dan fraksi air dilakukan uji fitokimia. Hasil uji fitokimia ekstrak dan fraksi dapat dilihat pada Tabel II.

Tabel II. Hasil uji fitokimia

\begin{tabular}{|c|c|c|c|c|}
\hline Metabolit Sekunder & $\begin{array}{c}\text { Ekstrak } \\
\text { etanol }\end{array}$ & $\begin{array}{c}\text { Fraksi } \\
\text { n heksan }\end{array}$ & $\begin{array}{c}\text { Fraksi Etil } \\
\text { Asetat }\end{array}$ & Fraksi Air \\
\hline \multicolumn{5}{|l|}{ Alkaloid } \\
\hline Dragendroff & + & + & + & + \\
\hline Mayer & + & + & + & + \\
\hline Saponin & + & - & + & + \\
\hline Fenolik & + & + & + & + \\
\hline Flavonoid & + & + & + & + \\
\hline Tanin & + & + & + & + \\
\hline
\end{tabular}

Keterangan:

$(+)=$ memberikan reaksi positif

$(-)=$ memberikan reaksi negatif

Berdasarkan uji fitokimia, ekstrak etanol, fraksi n heksan, fraksi etil asetat, dan fraksi air dari daun kersen mengandung alkaloid, fenolik, flavonoid, dan tanin.

Uji aktivitas antioksidan dilakukan dengan menggunakan metode DPPH dan aktivitas antioksidan dinyatakan dengan nilai $\mathrm{IC}_{50}$. Kontrol positif yang digunakan dalam penelitian ini adalah vitamin C (Praditasari, 2016). Vitamin C digunakan sebagai kontrol positif (senyawa pembanding) untuk mewakili antioksidan alami yang bekerja sebagai antioksidan sekunder yang menghambat aktivitas radikal bebas dan mencegah terjadinya reaksi berantai (Afriani et al, 2014). Kurva aktivitas antioksidan vitamin $\mathrm{C}$ dapat dilihat pada Gambar 1. 


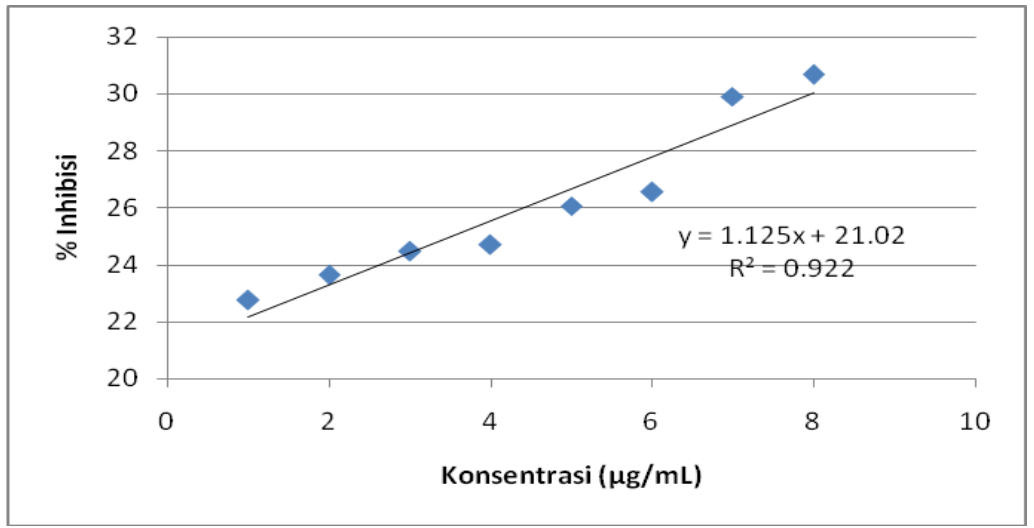

Gambar 1. Kurva aktivitas antioksidan vitamin C

Sampel ekstrak etanol, fraksi n-heksan, fraksi etil asetat, dan fraksi air diukur absorbansinya kemudian dihitung aktivitas penghambatnya (\% inhibisi) yang dibandingkan dengan absorbansi kontrol DPPH sehingga diperoleh nilai $\mathrm{IC}_{50}$ dari masing-masing sampel. Aktivitas antioksidan dari masing-masing sampel dan vitamin $\mathrm{C}$ dapat dilihat pada Tabel III.

Tabel III. Aktivitas antioksidan dari ekstrak etanol, fraksi n heksan, fraksi etil asetat, fraksi air dan vitamin $\mathrm{C}$

\begin{tabular}{cc}
\hline Sampel & $\mathbf{I C}_{\mathbf{5 0}}(\boldsymbol{\mu g} \mathbf{g} \mathbf{m L})$ \\
\hline Ekstrak etanol & $126,465 \pm 0,11$ \\
Fraksi n heksan & $101,355 \pm 0,21$ \\
Fraksi etil asetat & $79,372 \pm 0,25$ \\
Fraksi air & $129,854 \pm 0,22$ \\
Vitamin C & $25,776 \pm 0,14$ \\
\hline
\end{tabular}

Molyneux (2004) menyatakan bahwa nilai $\mathrm{IC}_{50}$ berbanding terbalik dengan aktivitas antioksidan suatu senyawa. Semakin besar nilai $\mathrm{IC}_{50}$ suatu senyawa maka kemampuan sebagai antioksidan semakin lemah. Berdasarkan Sinaga (2009), suatu senyawa yang mempunyai nilai $\mathrm{IC}_{50}$ kurang dari 50 ppm maka senyawa tersebut termasuk sebagai antioksidan sangat kuat. Jika nilai $\mathrm{IC}_{50}$ sebesar 50-100 ppm termasuk antioksidan kuat, $100-150$ ppm termasuk antioksidan sedang, dan $\mathrm{IC}_{50}$ lebih dari 500 ppm termasuk antioksidan lemah. Dari Tabel IV dapat dilihat bahwa fraksi etil asetat mempunyai $\mathrm{IC}_{50}$ yang paling kecil dibandingkan dengan ekstrak etanol, fraksi $\mathrm{n}$ heksan, dan fraksi air. Fraksi etil asetat mempunyai aktivitas antioksidan yang kuat. Penelitian Rachmani dan Suhesti (2016) dihasilkan bahwa $\mathrm{IC}_{50}$ fraksi etil asetat paling besar dibanding dengan ekstrak air, fraksi kloroform dan residu ekstrak herba sambiloto yaitu sebesar $395,01 \mu \mathrm{g} / \mathrm{mL}$.

Penentuan kandungan fenolik total dilakukan dengan metode Folin Ciocalteu menggunakan asam galat sebagai pembanding. Kurva baku asam galat dapat dilihat pada Gambar 2. 


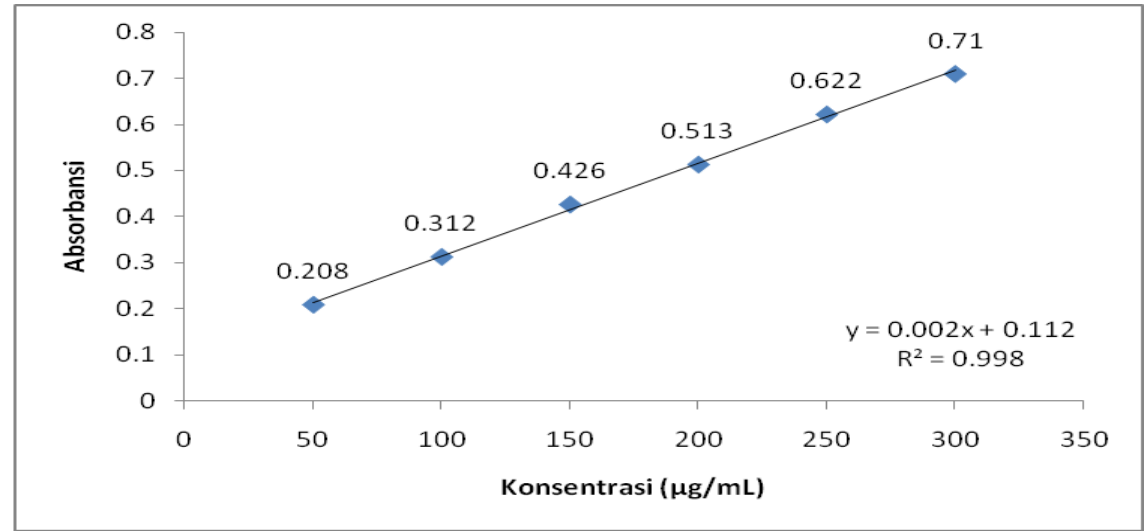

Gambar 2. Kurva baku asam galat

Kandungan fenolik total ekstrak etanol, fraksi $n$ heksan, fraksi etil asetat, dan fraksi air dapat dilihat pada Tabel IV.

Tabel IV. Kandungan fenolik total sampel

\begin{tabular}{cc}
\hline Sampel & Kandungan fenolik total (mg/gram) \\
\hline Ekstrak Etanol & $311,10 \pm 0,15$ \\
Fraksi n Heksan & $103,95 \pm 0,20$ \\
Fraksi Etil asetat & $510,57 \pm 0,17$ \\
Fraksi Air & $292,74 \pm 0,18$ \\
\hline
\end{tabular}

Dari Tabel IV dapat dilihat bahwa fraksi etil asetat memiliki kandungan fenolik total yang lebih besar dibandingkan dengan ekstrak etanol, fraksi n heksan, dan fraksi air yaitu sebesar 510,57 mg/gram.

Penentuan kandungan flavonoid total dilakukan dengan metode kolorimetri menggunakan pereaksi $\mathrm{AlCl}_{3}$ dan kuersetin sebagai pembanding. Kurva baku kuersetin dapat dilihat pada Gambar 3 .

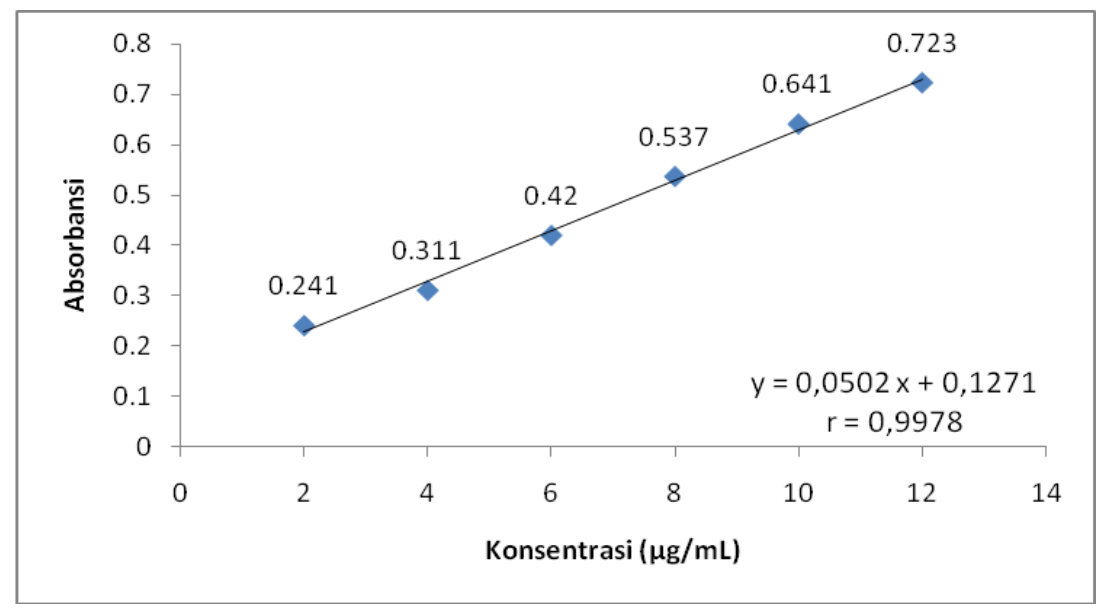

Gambar 3. Kurva baku kuersetin 
Kandungan flavonoid total ekstrak etanol, fraksi n heksan, fraksi etil asetat, dan fraksi air dapat dilihat pada Tabel V.

Tabel V. Kandungan flavonoid total ekstrak etanol, fraksi n heksan, fraksi etil asetat, dan fraksi air

\begin{tabular}{cc}
\hline Sampel & Kandungan flavonoid total (mg/gram) \\
\hline Ekstrak etanol & $39,63 \pm 0,08$ \\
Fraksi $n$ heksan & $3,30 \pm 0,11$ \\
Fraksi etil asetat & $76,32 \pm 0,15$ \\
Fraksi air & $14,29 \pm 0,18$ \\
\hline
\end{tabular}

Dari Tabel $\mathrm{V}$ dapat dilihat bahwa fraksi etil asetat mengandung flavonoid total paling besar dibanding ekstrak etanol, fraksi $\mathrm{n}$ heksan, dan fraksi air yaitu sebesar 76,32 mg/gram.

Fenolik adalah metabolit sekunder yang berperan penting dalam pemeliharaan kesehatan manusia. Kandungan fenolik pada tumbuhan menunjukkan aktivitas antioksidan yang dapat mencegah berbagai penyakit dengan cara peredaman radikal bebas (Meenakshi et al., 2012).

Flavonoid adalah suatu antioksidan alam dan mempunyai aktivitas biologis, antara lain sebagai antioksidan yang dapat menghambat berbagai reaksi oksidasi, serta mampu bertindak sebagai pereduksi radikal hidroksil, superoksida, dan radikal peroksil (Kuntorini et al., 2013). Hal ini dapat diasumsikan bahwa sampel yang mempunyai kandungan flavonoid total lebih tinggi mempunyai aktivitas antioksidan yang lebih tinggi. Kandungan senyawa flavonoid pada tanaman berkorelasi terhadap aktivitas antioksidan (Mbaebie et al., 2012). Flavonoid berperan terhadap aktivitas antioksidan. Posisi $\mathrm{OH}$ dan ikatan rangkap pada flavonoid berperan dalam peningkatan aktivitas antioksidan. $\mathrm{OH}$ pada $\mathrm{C}-3$ dan ikatan rangkap antara $\mathrm{C}-2$ dan $\mathrm{C}-3$ akan meningkatkan aktivitas antioksidan (Fridiani et al., 2014). OH pada posisi orto di C-3' dan C-4' serta gugus fungsional okso pada posisi C-4 berpengaruh paling besar terhadap aktivitas antioksidan (Heim et al., 2002).

Hasil analisis nilai $\mathrm{IC}_{50}$ menunjukkan bahwa fraksi etil asetat daun kersen yang merupakan hasil fraksinasi dari ekstrak etanol daun kersen memiliki aktivitas antioksidan lebih kuat dibandingkan dengan ekstrak etanol, fraksi $\mathrm{n}$ heksan, dan fraksi air. Hal ini disebabkan kandungan fenolik total dan flavonoid total fraksi etil asetat lebih besar dibandingkan dengan ekstrak etanol, fraksi n heksan, dan fraksi air. Kandungan fenolik total dan flavonoid total berkorelasi positif terhadap aktivitas antioksidan. Hal ini sesuai dengan penelitian Turkoglu et al., 2007; Jose dan Radhamary, 2017) yang menyatakan bahwa senyawa fenolik dan flavonoid berperan sebagai antioksidan dan agen peredam radikal bebas yang terkait dengan kerusakan oksidatif. Senyawa fenolik dan flavonoid secara in vitro menunjukkan aktivitas biologi seperti antiinflamasi, antitumor, dan aktivitas antimikroba.

\section{KESIMPULAN}

Ekstrak etanol, fraksi n heksan, fraksi etil asetat, dan fraksi air mengandung alkaloid, fenolik, flavonoid, dan tanin. Aktivitas antioksidan, kadar fenolik total, dan flavonoid total terbesar adalah fraksi etil asetat yaitu 79,37 $\mu \mathrm{g} / \mathrm{mL}, 510,57 \mathrm{mg} / \mathrm{gram}$ dan 76,32 mg/gram. Kadar fenolik total dan flavonoid total berkorelasi positif terhadap aktivitas antioksidan.

\section{UCAPAN TERIMAKASIH}

Penulis mengucapkan terima kasih kepada Kemenristekdikti yang telah memberikan dana penelitian melalui Skim Penelitian Dosen Pemula. 


\section{DAFTAR PUSTAKA}

Afriani, S., Idiawati, N., Destiarti L, Arianie L., 2014, Uji Aktivitas Antioksidan Daging Buah Asam Paya (Eleiodoxa conferta Burret) dengan Metode DPPH dan Tiosianat, Jurnal Kimia Katulistiwa, 3 (1): 49-56.

Blois, M.S., 1958, Antioxidant Determination by The Use of Stable Free Radical, Nature, 181: 11992000.

Chang, C.C., Yang, M.H., Wen, H.M., Chem, J.C., 2002, Estimation of Total Flavonoid Content in Propolis by Two Complementary Colorimetric Methods, J.Food Drug Anal,10: 178-182.

Danugroho, E.S., dan Widyaningrum, N.R., 2014, Aktivitas Analgesik Infusa Daun Kersen (Muntingia calabura L.) pada Mencit Jantan Ras Swiss, Indonesian Journal On Medical Science, 1 (2): 5657.

Fridianny,I., Darmawati, A., Sukrasno, 2014, Antioxidant Capacities from Different Polarities Extracts of Cucurbitaceae leaves using FRAP, DPPH Assay and Correlation with Phenolic, Flavonoid, Carotenoid Content, Int J Pharm Sci, 6 (2): 858-862.

Harborne, J.B., 1987, Metode Fitokimia Penentuan Cara Modern Menganalisis Tumbuhan, diterjemahkan oleh Padmawinata, K., Bandung:ITB.

Heim, K.E., Tagliaferro, A.R., Bobilya, D.J., 2002, Flavonoid antioxidants: Chemistry, metabolism and Structure Activity Relationship, J Nutr Biochem, 572-584.

Jose, S., dan Radhamany, P.M., 2012, Identification and determination of antioxidant constituents of bioluminescent mushroom, Asian Pac. J. Trop Biomed, 2: 386-391.

Kuntorini, E.M., Fitriana, Setya, dan Astuti, M.D., 2013, Struktur Anatomi dan Uji Aktivitas Antioksidan Ekstrak Metanol Daun Kersen, Prosiding, Semirata FMIPA Universitas Lampung, 291-296.

Latifah, Ismi., 2015, Uji Aktivitas Antioksidan Ekstrak Daun Kersen (Muntingia calabura L.) dan Daun Waru (Hibiscus tiliaeceus L.) dengan Metode DPPH (2,2-difenil-1-pikrilhidrazil), Skripsi, Jurusan Kimia Fakultas Sains dan Teknologi Universitas Islam Negeri Sunan Kalijaga, Yogyakarta.

Lee, S.E., Hwang, H.J., H, J.S., Jeong, H.S., and Kim, J.H., 2003, Screening of medicinal plant extracts for antioxidant activity, Life Sci, 73: 167-179.

Manik, D.F., Hertiana, T., dan Anshory, H., 2014, Analisis Korelasi antara Kadar Flavonoid dengan Aktivitas Antibakteri Ekstrak Etanol dan Fraksi-fraksi Daun Kersen (Muntingia calabura L.) terhadap Staphyilococcus aureus, Khasanah, 6 (2), 1-11.

Mbaebie, B.O., Edeoga, H.O., dan Afolayan, A.J., 2012, Phytochemical analysis and antioxidant activities of aqueous leaf bark extract of Schotia latifolia Jacq, Asian Pac. J. Trop. Biomed, 2: 118-124.

Meenakshi, S., Umayaparvath, S., Arumugam, M., and Balasubramanian, T., 2012, In vitro antioxidant properties and FTIR analysis of two seeweeds of Gulf of Mannar, Asian Pac. J. Trop. Biomed, 2: 66-70.

Molyneux, P., 2004, The Use of The Stable Free Radical Diphenil Diphenylpicrylhidrazyl (DPPH) for Estimating Antioxidant Activity, Songklanakarin J.Sci. Technol, 26 (2): 211-219.

Nishanthini, A., A. Agnel Ruba, V.R Mohan, 2012, Total Phenolic, Flavonoid Contens and In Vitro Antioxidant Activity of Leaf of Suaeda monoica Forssk ex Gmel (Cenopodiaceae), International Journal of Advanced Life Sciences (IJALS), 1 (5): 34 - 43.

Onkar, P., Bangar, J., and Karodi, R., 2012, Evaluation of Antioxidant activity of traditional formulation Giloy satva and hydroalcoholic extract of the Curculigo orchioides Gaertn, Journal of Applied Pharmaceutical Science, 02 (06): 209-213.

Pourmorad, F., Hosseiinimehr, S.J., Shahabimajd, N., 2006, Antioxidant Activity, Phenol and Flavonoid Content of Some Selected Iranian Medicinal Plants, Afr J Biotechnol, 5 (11): 11421145 . 
Praditasari, A., 2016, Review: Metode Uji Aktivitas Antioksidan Secara In Vitro pada Ekstrak Tanaman, Jurnal Farmaka, 14 (4): 1-12.

Puspitasari, A.D., dan Prayogo, L.S., 2016, Perbandingan Metode Ekstraksi Maserasi dan Sokletasi terhadap Kadar Flavonoid Total, Jurnal Ilmu Farmasi \& Farmasi Klinik, 13 (2): 16-23.

Race, S., 2009, Antioxidant: The Truth About BHA, BHT, TBHQ and Other Antioxidants Used As Food Additives, Tigmor Book : London.

Rachmana, E.P.N., dan Suhesti, T.S., Aktivitas Antioksidan Ekstrak dan Fraksi Herba Sambiloto (Andrographis paniculata), Media Pharmaceutica Indonesia, 1 (2): 100-105.

Shirmila, J.G., and Radhamany, P.M., 2013, Invitro Antioxidant Activities, Total Phenolics and Flavonoid of Wild Edible Mushroom Macrolepiota mastoidea (fr.) Singer. International Journal of Pharmacy and Pharmaceutical Sciences. 5 (2) : 161-166.

Sinaga, I.L.H., 2009, Skrinning Fitokimia dan Uji Aktivitas Antioksidan dari Ekstrak Etanol Buah Terong Belanda (Solanum betaceum Cav.), Skripsi, Fakultas Farmasi Universitas Sumatra Utara

Siddiqua, A., Premakumari, K.B., Sultana, R., Vithya and Savitha, 2010, Antioxidant Activity and Estimation of Total Phenolic Content of Muntingia Calabura by Colorimetry, International Journal of Chem Tech Research, 2 (1): 205-206.

Turkoglu, A., Duru, M.F., Mercan, N., Kivrak, I., dan Gezer, K., 2007, Antioxidant and antimicrobial activities of Laetiporus sulphureus (Bull.) Murill, Food Chem, 101: 267-273.

Winarsi, H., 2011, Antioksidan Alami dan Radikal Bebas, Yogyakarta: Kanisius

Yuliarti, N., 2008, Racun di Sekitar Kita, Andi offset, Yogyakarta, 25-28. 